\title{
Founders’ Education and SME Performance in Kosovo
}

\author{
Njomza Latifi- Mustafa ${ }^{1} \&$ Ymer Havolli $^{1}$ \\ ${ }^{1}$ Faculty of Economy, University of Prishtina, Kosovo \\ Correspondence: Dr. Ymer Havolli, Faculty of Economy, University of Prishtina, Kosovo. E-mail: ymer.havolli@ \\ uni-pr.edu
}

Received: February 26, 2020; Accepted: March 11, 2020; Published: March 14, 2020

\begin{abstract}
This research deals with the professional preparation of the founders of the SME sector in Kosovo, and also aims to present the state of abilities and skills of the founders of SMEs. Also of interest in this research is the analysis of the skills of managers, founders of SMEs, what is their perception regarding the reflection of education in the SME business, namely what is their performance which should be reflected in the success and development of SMEs. The paper therefore aims to analyze the education and reflection of this education on the success of SMEs. Economic and social development in Kosovo, and elsewhere, depends on the success of SME owners and managers. This management structure will be able to move SMEs forward if they have an important factor such as education and experience in the sector where the SME operates. This paper explores the professional background of the founders, the size of the business structure, the experience of the founders in the field where the SME was founded, the age at the time of its establishment, the impact of technology.
\end{abstract}

Keywords: education, small and medium enterprises, experience, age

\section{Introduction}

The private sector, and in particular the SME sector, is a generator of Kosovo's economic development. In addition to economic growth, the SME sector is generating new jobs and economic growth, as well as improving the welfare and reducing the poverty level which is high in Kosovo. However, the private sector's contribution would be deficient without a friendly business environment. Moreover, it is a widely accepted the fact that a favorable business environment and a well-developed business play an important role in international economic integration (Williams and Krasniqi, 2018; Havolli and Ahmeti, 2013; Hashi and Krasniqi, 2011; Krasniqi 2006).

Despite the many challenges that the private sector in Kosovo has consistently faced, recent years have seen an improvement in the business climate in the country. According to the World Bank's Doing Business Report 2017, Kosovo ranks 60th out of 190 economies. Compared to the previous year, Kosovo is ranked 4 places higher this year. However, despite this progress, always according to this report, all neighboring countries are ranked higher; thus, they have a more favorable business environment. To illustrate, Albania ranks two positions higher than Kosovo, while Serbia, Montenegro and Macedonia rank 47, 51 and 10 respectively. This small progress is mainly attributed to the facilitation of various administrative procedures related to businesses such as procedures for business registration, access to the electricity grid, property registration, etc. (Riinvest Institute, 2017).

The importance of the SME sector as a driver of economic development is now widely accepted, but it should be said that in Kosovo more emphasis is placed on SME performance in the market, and very little has been explored the impact of the education of entrepreneurs and managers, and the reflection of education on the effects of SMEs (Williams and Krasniqi, 2018; Krasniqi, \& Lajqi, 2018; Voca and Havolli, 2019). Usually the research done so far has dealt with the structure, the number of employees, while education has only been analyzed from the perspective of the structure of SME employees in Kosovo.

The sectoral structure of SMEs in Kosovo is not good, over $50 \%$ of all SMEs operate in the commercial sector, while the manufacturing sector has been steadily declining, while services are growing.

Macroeconomic indicators suggest that Kosovo's economy has made progress in 2019 with economic growth of $4.3 \%$. Kosovo's SME development marks an increase in terms of business registration over the years. Hence, in 2000 there were 14656 SMEs registered, while by the end of 2019 this number has reached around 183,386 SMEs (Kosovo Agency of Statistics, 2019). By years these SMEs have on average employed workers according to the table below. 
Table 1. Average number of employees in an SME by years

\begin{tabular}{lcccccccccccc}
\hline Years & 2000 & 2001 & 2002 & 2003 & 2004 & 2005 & 2006 & 2007 & 2012 & 2013 & 2015 & 2016 \\
\hline $\begin{array}{l}\text { The average number } \\
\text { of SME employees } \\
\text { in Kosovo }\end{array}$ & 11.1 & 10.4 & 8.1 & 10.5 & 15.1 & 16.1 & 14 & 15 & 7.1 & 6.9 & 8.5 & 8.8 \\
\hline
\end{tabular}

Source: Riinvest Institute, Business Climate in Kosovo from a Business Perspective, 2017

In terms of business registration it can be said that there is entrepreneurial initiative. However, it should be noted that there is no institutional supportive environment for this sector. In addition, the SME sector in Kosovo is characterized by weak links with the foreign market, limited opportunities for financial, technological support, with significant obstacles within the country in terms of support, and obstacles to overseas trade development and cooperation due to Kosovo's non-integration so far.

\section{Literature Review}

The concept of the importance of human capital education is obsolete. Perhaps the first who attempted to quantify and measure the effects of the education of the people employed by the firms was Sir William Petty (1623-1687) (Petty, 1690). William Petty was the most prominent founder of the Political Arithmetic School of Economics and a precursor to applied econometrics. Petty was preoccupied with the socio-economic, political, and national role of Human Capital. He believed that the work was the "father of wealth" and that some measure of its value should be included in the valuation of national wealth. Petty's thesis was, that factors other than land and population were important in determining a nation's wealth (Folloni and Vittadini, 2011). It has already been established that human resources, their education and knowledge are the primary sources of development to which societies give priority in their national strategies and policies. Many developed economies, their national development strategies have put on their focus precisely the human factor and its permanent education (Havolli, 2004). In this sense, 'the role of higher education institutions as human resource producers' has never been more important, considering what we face today, with the development of individual and general well-being, which is based on knowledge in the society" (Bleiklie, 2007).

Further, the business education system broadly focuses on the formation of work skills and social characteristics essential for the creation of healthy personal employee relationships. This is a recurring cycle based on corporate strategy objectives and also based on the principles of corporate training policy. This cycle is further supported by the conditions of the organizations they possess to support the development of human resources in the organization (Holden, \& Biddle, 2017).

For most people, equity means a bank account, a hundred shares of IBM, assembly lines or steel plants in the Chicago area. These are all forms of capital in the sense that they are assets that yield income and other useful results over long periods of time. But such tangible forms of capital are not the only type of capital. Education, a computer training course, medical care costs and lectures on the virtues of punctuality and honesty are also capital. This is because they increase profits, improve health, or enhance a person's good habits throughout most of his life. Therefore, economists consider spending on education, training, medical care, etc., as investment in human capital (Becker, 1992).

Benefits - the return on these skills is individual in the sense that an individual's productive ability grows more. But there are externalities which increase the productive capacity of others when human capital is increased (Goldin, 2016). Skills possessed by human resources are valued as a resource or asset. The Oxford English Dictionary states that "... when investments in people (eg, education, training, health) exist, these investments increase the productivity of the individual's work (Oxford English Dictionary).

Theodore Schultz, says: "I propose that education be treated as an investment in people and its importance treated as a form of capital, since education becomes an integral part of the person receiving it, I will refer to it as human capital. " (Schultz 1960). In addition, in his book Wealth of Nations Adam Smith discusses the economic value that education has.

Education is the process of "producing" human capital, while training, namely acquiring the skills needed because of the changes that occur and due to the needs of the firm, increases the value of that capital. The initiators of the idea of human capital are A. Smith (division and specialization of work) K. Marx (The Role of Science and Technology in Production), J. S. Mill (Quantity and quality human abilities to work), J. Schumpeter 
(recombination of knowledge into process innovation as a factor of economic growth) (Savvides \& Stengos, 2009).

These authors' reviews show that businesses in whatever form are organized should be committed to the capacities of the people they employ to enable them to use their knowledge, skills and experience for business activity. These human capital capacities have long been and still are intended to be used in order to increase efficiency and effectiveness in the organization. On the other hand, human resources are constantly changing, as circumstances change in the business environment, and such change should related to the increase in education, abilities, and skills that are valuable to SMEs.

\section{Methodology}

A survey was conducted for this research which included 500 SMEs in all regions of Kosovo. The research has been focused on surveying SME Management members, and in particular those members who are well informed about enterprise business. This means that the respondents in this research were the owners, managing directors, and decision makers in the area of finance. In most cases these criteria have been met.

The data collection was done through a survey questionnaire by directly contacting the responsible persons of SMEs. Nearly 35 student-associates engaged in field surveying and control were engaged in the field data collection. One-day training was organized for this research in order to familiarize the respondents with the aims of the survey and its implementation, the content and manner of contacting the respondents, data collection and the manner of technical implementation of the survey. Data processing was done in Excel and SPSS. The processing of the collected data has created opportunities for analysis, comparisons and conclusions regarding the state and trends of SME development in Kosovo. Margin of error of this survey $\pm 3 \%$, ensuring the reliability of survey results.

\section{Education of SME Founders in Kosovo}

Small and medium-sized enterprises play an important role in the economy, families and are subjects that are always striving for international economic cooperation. This cooperation paves the way for Kosovo even more to cope with economic stagnation, reduce unemployment and enable the integration of the SME sector into mainstream economic developments. SMEs through their creativity and partnerships will certainly establish even more contacts with international businesses, or indirectly through doing business (import and export). Opening up opportunities for free movement of managers - that is, liberalization, would give impetus to economic cooperation and employment growth.

\subsection{Professional Training of Founders}

There is also an important element that will drive SMEs forward with development and collaboration, namely the element of educating the owners and managers who manage these companies. It is very important that this part of the management, and of the entrepreneurs, is prepared to know the processes and strategic construction of the development of these SMEs. The Figure 1 presents the educational level of the founders of SMEs in Kosovo in comparison with other transitional countries (now part of EU).

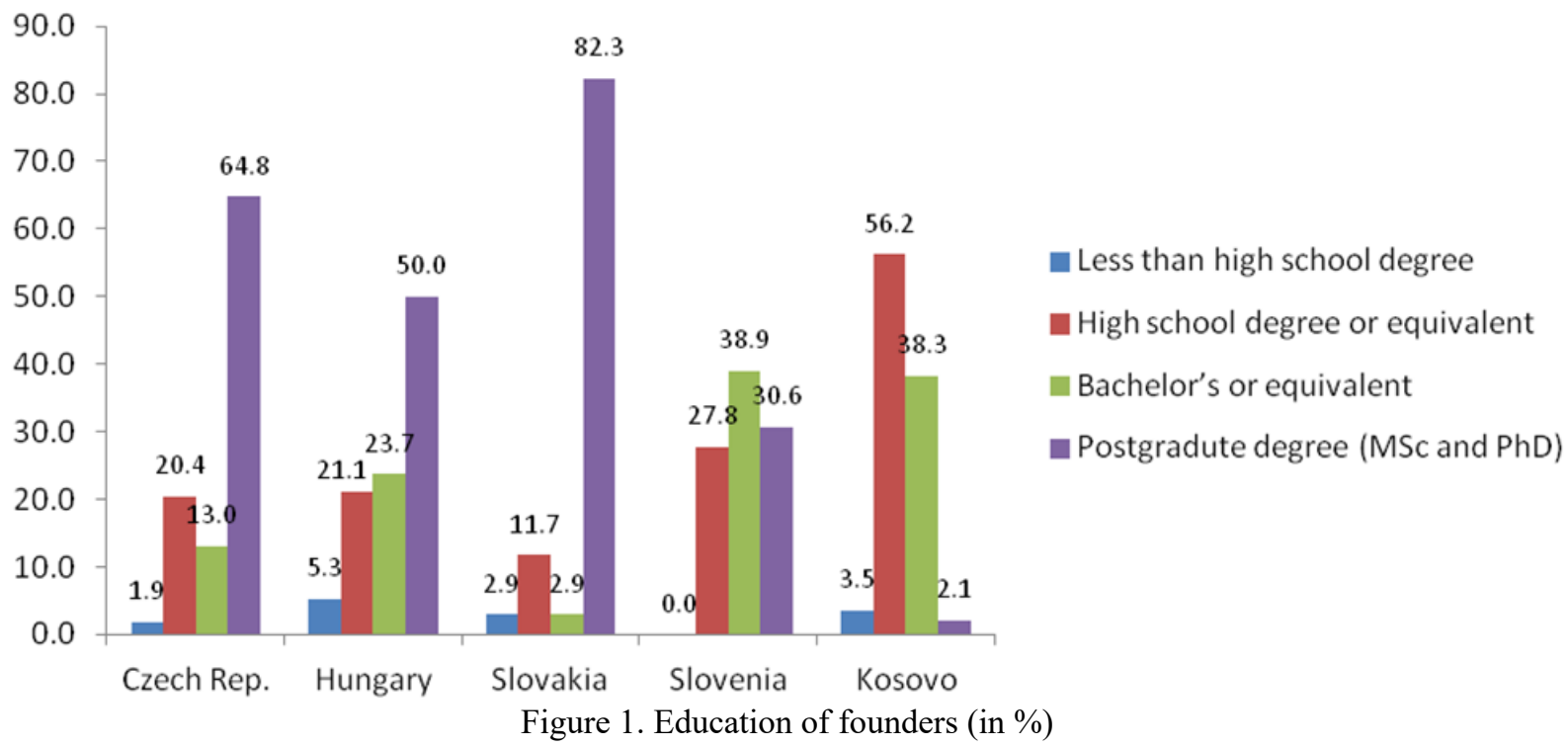


Source: For Kosovo: Survey of 500 SMEs throughout Kosovo and for other countries based on European Union (2018) Annual Report on European SMEs 2017/2018.

There is no doubt that basic education generally enhances the managerial quality of the owner / manager by providing him / her with basic numeracy and literacy skills, so this education increases the chance of survival (see, for example, Carter and Jones-Evans, 2000; Katwshe, 1994). The discussion on the educational level of the owner / manager tends to be divided into two schools of thought. Some studies state that the fact that a manager holds a higher education degree or even a postgraduate degree seems to stimulate firm growth, thus having an impact on survival and growth. However, others disagree, arguing that the owner / managers of SMEs who had degrees generally achieved lower outcomes than those with less education, or less educated (Hall, 2000; Barkham et al., 1996).

Coming up with a creative solution does not come easily and immediately. In fact, the path one has to take to get to the solution most of the time is accompanied by a dose of uncertainty and confusion. This is because of the level of education, which makes the managerial structure because of limited knowledge uncertain, and on the other hand, the limited ability of these people to make creative solutions in order to manage SMEs toward success. If we refer to research we still have some kind of gap in management education and for its ability to design the success strategy of the SME that manages it. If we aggregate the data it results that $59.7 \%$ are with secondary school and $3.5 \%$ with primary school. Compared to other countries in Figure 1, Kosovo has significantly less SME founders with postgraduate education. In terms of university education of founders, Kosovo $(38,3 \%)$ is at comparable level with the Slovenia (38.9\%). In comparison with other countries where postgraduate level of education of founders is dominant (with exception of Slovenia), in Kosovo high school education of SME founders has the highest share.

The growth of small and medium-sized businesses in Kosovo will depend on the continued success of small business owners. An important factor for the success of SMEs and the economy of Kosovo in general is the level of education, and the complementary Long Life learning of business owners. Research has shown that $38.3 \%$ of owners and founders possess university education and only $2.1 \%$ have post-university education. The formal and informal education system has the chance to correct this disadvantageous structure for SME development. Berns (1991) studied 9,000 entrepreneurs and found that continuing education in financial management, personnel, marketing and business planning was regularly required by businesses.

\subsection{What Enterprises have SME Owners Created?}

The competitive activity of SMEs in the market constantly requires ways and space in order to cope with the competition, and this also requires raising the level of education of managers and owners. Their inadequate education is likely to result in inadequate results expected from these enterprises. This actually has other consequences that are reflected in the development, growth and slow development of SMEs in Kosovo, and often the failure of many of them precisely because of their poor management. Only during 2019 in the third quarter (Q3) 1769 businesses were shut down. If these businesses hired only the owner, only within a quarter there were 1,769 employees left unemployed. Education of entrepreneurs, therefore, is a critical function of business development and expansion of employment and welfare of SMEs.

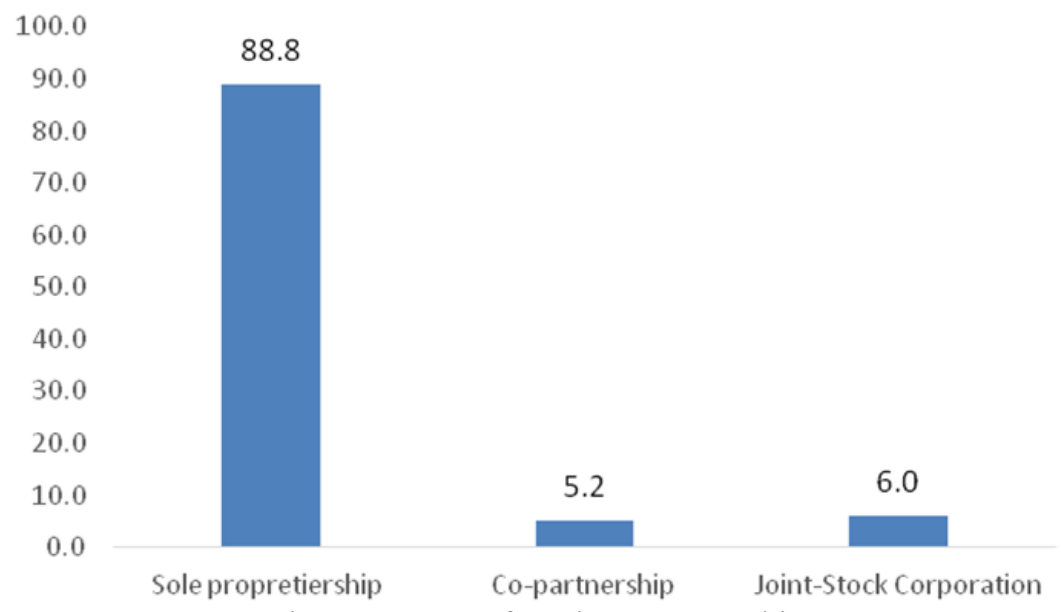

Figure 2. Type of Business Ownership

Source: survey of 500 SMEs throughout Kosovo 
Unemployment and quality of life in Kosovo can be said to be one of the elements for entrepreneurs to start realizing their ideas, and to start up new businesses, regardless of their level of education, preparation to enter the business. Unemployed people, therefore, seek alternative employment options of their own, and of an active labor market contingent, who are unemployed and who wait long for employment. The unemployment rate in Kosovo is $29.6 \%$. This level of unemployment is another reason for starting a new business. We argue this with the dominance of individual businesses $(88.8 \%)$. However, the share of partnerships on the other hand is very small $(5.9 \%)$, same as that of the joint stock companies $(6 \%)$. So, the business overview in the fourth quarter (Q4) "in the category of 1 to 4 employees (micro enterprises) there are a total of 2486 enterprises registered in this quarter - Q4 (96.9\%), with 5 to 9 employees there are $53(2.1 \%), 10$ to 19 employees there are $18(0.7 \%), 20$ to 249 employees there are $9(0.4 \%)$ and in the category of 250 and more employees we have no company registered in this quarter (Statistical Repertoire on Economic Enterprises in Kosovo, 2019).

\subsection{What has been the Main Reason for Entrepreneurs to Open a Firm?}

There is another reason why this overviews is such. Unprofessional people are reluctant to take the risk of investing their capital in the idea that they have. Whereas when conditionally it could be said that risk is low, they entered into doing business but in most of the cases by "copy catting" each other. In such cases, this type of entrepreneurs in order to set up an individual business they considered lower investment, and consequently lower risk as a good idea, by employing themselves and frequently their family members. SMEs, however, represent an alternative way for many unemployed people in Kosovo to make choices and achieve the optimal level of life they want. Alternative employment solutions are therefore required for a contingent of unemployed at a time when unemployment in Kosovo is $29.6 \%$.

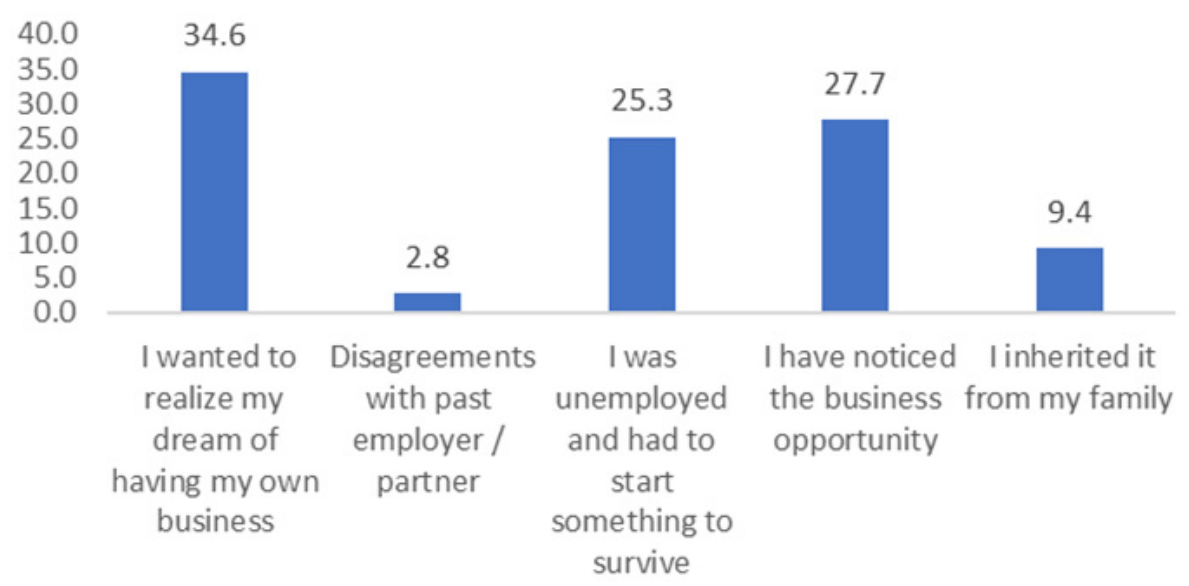

Figure 3. The Main Reason for Opening the Firm

Source: survey of 50 SMEs throughout Kosovo

SMEs play a key role in countries in transition and developing countries. These firms typically account for more than $90 \%$ of all firms outside the agricultural sector, constitute a major source of employment, and generate domestic income and exports. As such, SME development appears to be a key instrument in poverty reduction efforts (OECD, 2004). There is usually a reason that entrepreneurs start their own businesses. However, it is good that everyone's dream of starting a business will help Kosovar entrepreneurs have an experience, as always being an employee before you become an employer helps. In the SME sector we have a percentage $(34.6 \%)$ of entrepreneurs who dreamed of materializing their idea and their dream came true. This is also approximate with entrepreneurs' responses related to prior experience which is solid in this case ( $41 \%$, see pg 4$)$. Some entrepreneurs had no choice but to start a new business (25.3\%).

The moment when entrepreneurs have noticed an important business opportunity, is the moment when curiosity is aroused for an opportunity of doing business. Part of the respondents answered that they noticed this opportunity (27.7\%), and seized it. A percentage of businesses were inherited (9.4) and they usually follow the family tradition of doing business.

\subsection{Experience in Business}

This part of the analysis examines the element of experience. This actually reflects in a way the presence of the human capital element, the entrepreneurial experience when starting a business. If we analyze the survey data of 
500 SMEs in Kosovo, we will find that most of the problems that SMEs face are precisely the experience in the specific area in which the enterprise was founded.

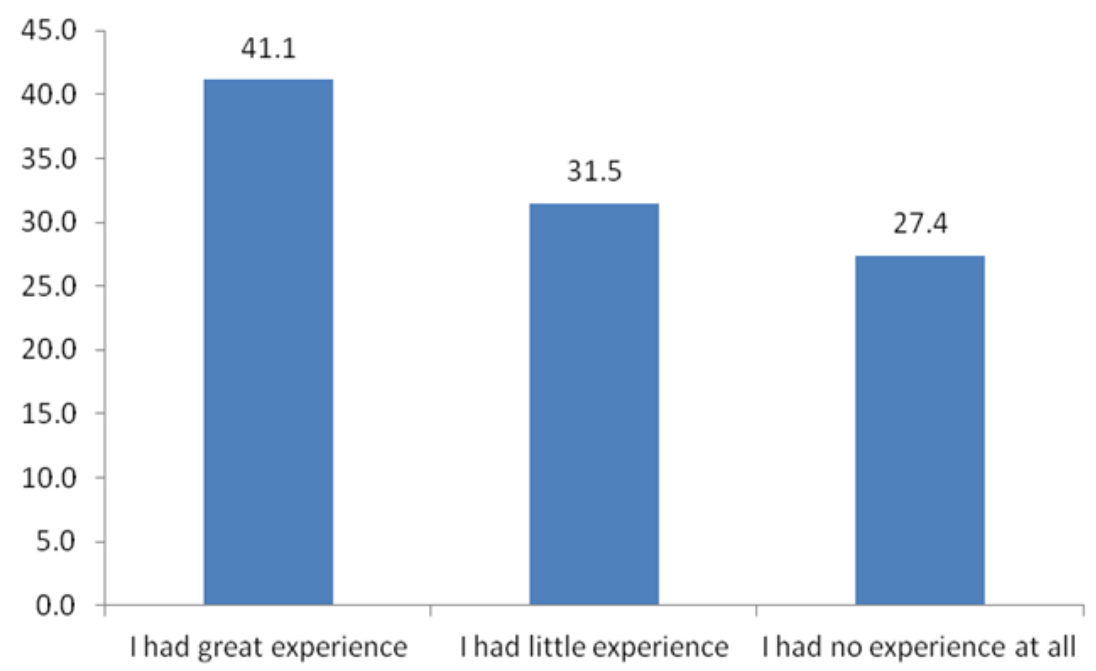

Figure 4. Have you had experience in the area in which you started your business?

Source: survey of 500 SMEs throughout Kosovo

Research has shown that $41 \%$ of founders have a positive relationship with experience. Whereas the other two categories together constitute $58.9 \%$, SMEs have a negative relationship with experience. This relation is confirmed by the results of a survey in which entrepreneurs stated that $31.5 \%$ had little experience. Whereas, $27.4 \%$ had no experience in the area where they started their business. SME owners or managers are empowered to make decisions. Hence, here is seen as an obstacle the abilities and skills and knowledge to identify the internal environment, and especially the external environment, how and to what extent they affect SME performance and therefore make the right decisions. or the experience of dealing with human capital and other assets of SME in this environment. This refers to personality and building of the manager in business, his attitudes, which derive from previous education and experience in business. Businesses surveyed in Kosovo stated that only $41.1 \%$ of them have sufficient experience, while the remaining $58.9 \%$ are in the risk zone or fortune which in these cases relates to hazard in doing business.

Studies have generally shown that SME owners / managers with more managerial experience in the sector or previous SMEs as owner / manager tend to be associated with greater growth (Storey et al., 1989).

\subsection{Age at the Time of Establishment}

The age of the owner / manager and his impact on the business growth is another important factor. Theoretically, if we refer to age, then we can say that the younger age is more active and bolder when making decisions, the younger age is more motivated and so on.

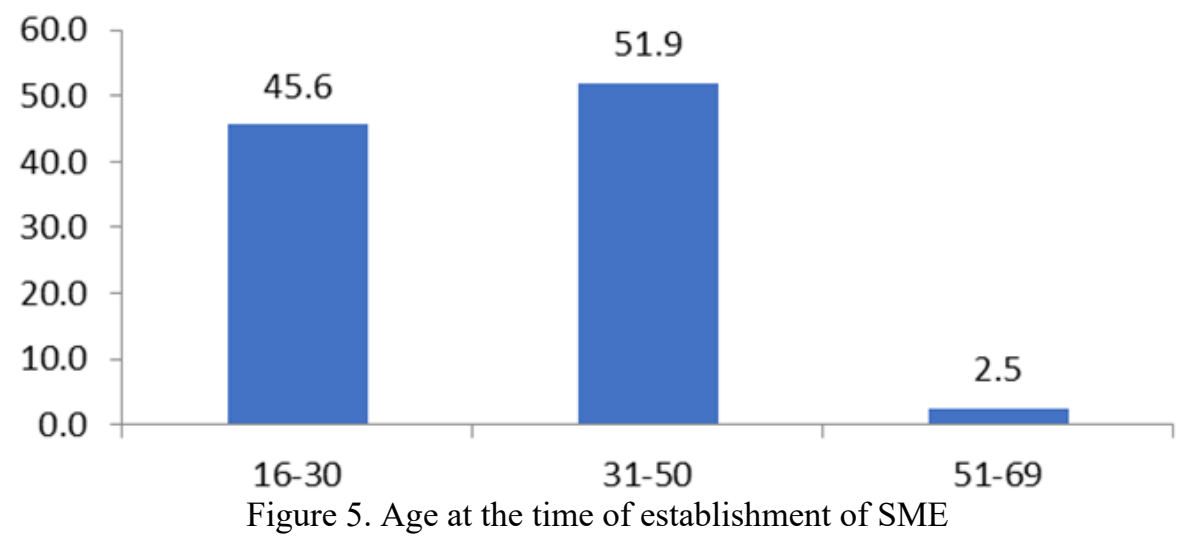

Source: survey of 500 SMEs throughout Kosovo 
In our research the percentage of 16-30 years of age, as depicted in chart no. 5 . is $45.6 \%$. If we add the two most productive ages $(16-30+31-50)$ we will have a sum of $96.5 \%$. This reflects that founders and managers by age are in their most productive years of life to give impetus to SME development.

\subsection{Impact of Technological Component}

The impact of technology is everywhere reflected in the growth or decline of SMEs. Applying technology gives great chances for growth, while on the other hand the lack of change most probably will result in decline of SMEs. Also new technology has implications for the development of human capital in the enterprise. This means that new technology requires new investment in human capital in the company; for training, workshops, seminars, etc., in order to adopt the use and maintenance of that technology. Technology and its application also affects the workforce in different sectors. For example, the implementation of IT in the banking system has led to the reduction of employees in Kosovo banks. However, science has proven that the application of technology creates new opportunities and new job. Normally this technology requires well educated people in the SME sector. Therefore new technology attracts investment in new capacity building of human capital.

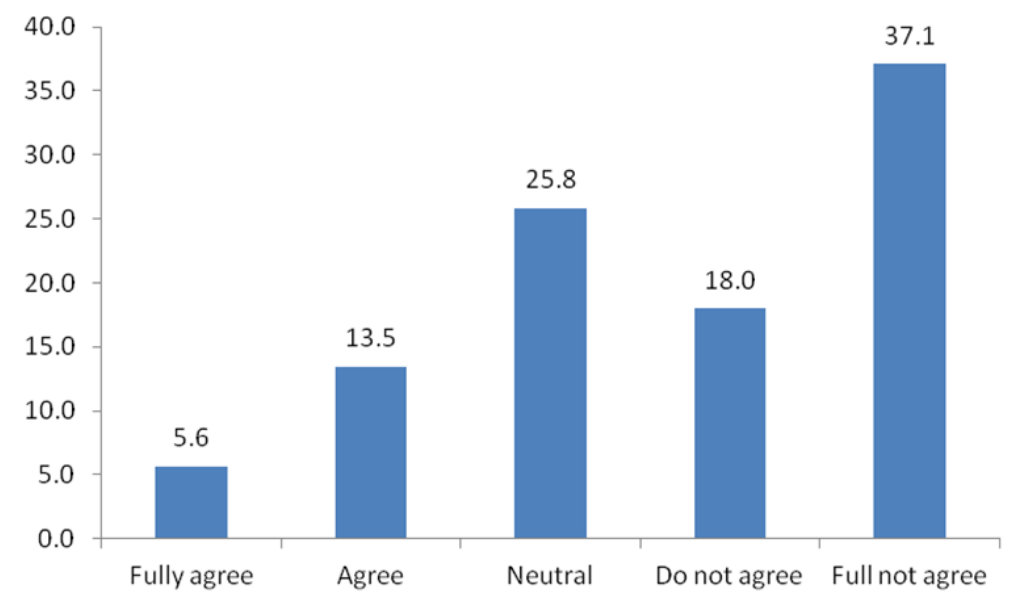

Figure 6. Technological competence

Source: survey of 500 active SMEs throughout Kosovo

The degree of technological competence of human capital has helped SMEs and has proved advantageous to them. If we aggregate the category "completely agree" (5.6\%) and "agree"(13.5\%), then we can say that respondents answered that they agree, and $19.1 \%$ completely agree. The percentage given by the respondents is very significant. This actually shows that a significant portion of human capital, "disagree", are "neutral", and "completely disagree", ie the connotation of fear of change is $80.1 \%$. This $80.1 \%$ agrees with the current situation, we can assume that it is afraid of change, and this part as such is not part of the creative human capital that supports the changes and development of this sector.

To effectively achieve the desired change, executives need to start as a model, from their behavior to issues related to customers, employees and stakeholders, before being subjected to subordinates. This should be approached gradually and systematically. Investing in technology will allow SMEs to solve product-related problems and combine human, technical and conceptual abilities to handle change as it occurs in a dynamic business environment (Durowoju, 2017).

\subsection{The Correlation Matrix between Different Dimensions}

The correlation matrix has been our focal point of research. We have therefore attempted to correlate the dependent variable, education through independent variables, sales or profit margin.

Table 2. Correlations matrix

\begin{tabular}{llllll}
\hline & & Age & Education & Sales & Profit margin \\
\hline Age & Pearson Correlation & 1 & -.069 & .066 & -.060 \\
& Sig. (2-tailed) & & .107 & .125 & .177 \\
Education & $\mathrm{N}$ & 572 & 547 & 548 & 506 \\
& Pearson Correlation & -.069 & 1 & $.133^{* *}$ & -.012 \\
\hline
\end{tabular}




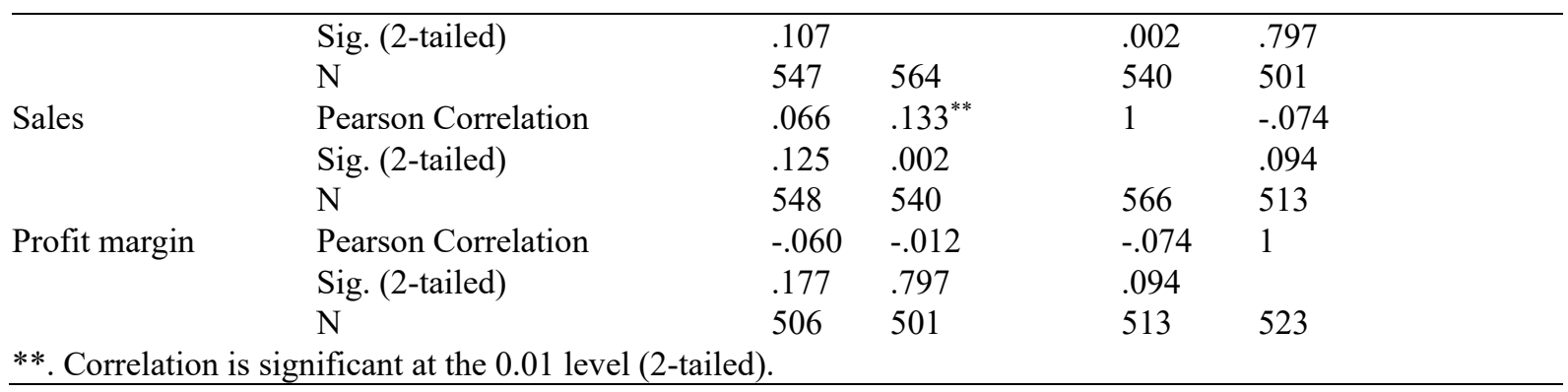

From the above table which indicates the correlation between dependent variables education, and independent variables; age, sales, and profit margin we see the correlation between these variables.

There was a very low negative correlation (-069) between the dependent variable education and the independent variable age. The negative correlation in this case indicates that one variable increases (age) and the other (education) decreases.

In the correlation between education and sales there is a significant positive relationship between annual sales and education. The correlation coefficient was calculated to be .133. In this case we can say that as the level of education and forms of education (training, workshops, etc.) change, sales also change.

To further analyze the dependent variable, Education, and determine which independent variables (such as sales and profit margin) affect SME activity. Parameter estimates indicate that the higher level of education of business owners $(0.002<0.05)$ has a significant impact on sales and profit margin increases. On the other hand, age $(0.066>$ 0.05 ) did not show statistical significance, thus this variable has no significant effect on sales growth or profit margin.

\section{Key Findings}

Small and medium-sized enterprises play an important role in the economy, families and are subjects that are always striving for international economic cooperation. This cooperation paves the way for Kosovo even more to cope with the economic stagnation, unemployment reduction and integrates it into the general developments of this sector.

Opening up opportunities for free movement of managers - i.e liberalization, would give impetus to economic co-operation and employment growth. However, there is also an important element that will drive SMEs forward with development and collaboration, namely the element of educating the owners and managers who manage these companies.

If we refer to research we still have some kind of gap in management education and for its ability to design the success strategy of the SME that manages it. If we aggregate the data it results that $59.7 \%$ are with secondary school and $3.5 \%$ with primary school.

The unemployment rate in Kosovo is $29.6 \%$. This level of unemployment is another reason for starting a new business

We argue this with the dominance of individual businesses (88.8\%). However, the share of partnerships on the other hand is very small (5.9\%), same as that of the joint stock companies $(6 \%)$.

In the SME sector we have a percentage (34.6\%) of entrepreneurs who dreamed of materializing their idea and their dream came true. This is also close to the responses of entrepreneurs with prior experience which in this case is solid $(41 \%$,). Some entrepreneurs had no choice but to start a new business $(25.3 \%)$.

Research has shown that $41 \%$ of founders have a positive relationship with experience. Whereas the other two categories together constitute $58.9 \%$, SMEs have a negative relationship with experience. This relation is confirmed by the results of a survey in which entrepreneurs stated that $31.5 \%$ had little experience. Whereas, $27.4 \%$ had no experience in the field where they started their business.

In our research the percentage of 16-30 years of age as seen in the figure 5 is $45.6 \%$. If we add the two most productive ages (16-30 + 31-50) we will have a sum of $96.5 \%$.

The level of competence in the responses "fully agree (5.6\%) and "agree" $(13.5 \%+13.5 \%) 19.1 \%$ completely agree. This actually shows that a significant portion of human capital, "disagree", are "neutral", and "completely 
disagree", ie the connotation of fear of change is $80.1 \%$. This $80.1 \%$ agrees with the current situation, we can assume that it is afraid of changes.

\section{References}

Berns, R. G. (1991). Entrepreneurship in the year 2000. Vocational Education Journal, 66(2), 44.

Bleiklie, I. (2005). Organizing higher education in a knowledge society. Higher Education, 49(1-2), 31-59. https://doi.org/10.1007/s10734-004-2913-7

Carter, S. and D. Jones-Evans (Eds.) (2000). Enterprise and Small Business - Principles, Practice and Policy. Harlow: FT Prentice Hall. https://doi.org/10.1108/00251740810882707

Carter, S., \& Jones-Evans, D. (Eds.). (2006). Enterprise and small business: Principles, practice and policy. Pearson Education.

Durowoju, S. T. (2017). Impact of Technological Change On Small and Medium Enterprises Performance in Lagos State. Economic and Environmental Studies, 17(44), 743-756. https://doi.org/10.25167/ees.2017.44.7

Gary S. Becker (1992). The Economic Way of Looking At Life* Nobel Lecture, December 9, 1992 G ARY S. Becke R Department of Economics, University of Chicago, Chicago, IL. 60637, USA, p. 44.

Giuseppe, F., \& Giorgio, V. (2009). HUMAN CAPITAL MEASUREMENT: A SURVEY: Jurnal of Economic Surveys, 24(2), prill 20110, fq 248-279. https://doi.org/10.1111/j.1467-6419.2009.00614.x

Goldin, C., \& Katz, L. F. (1999). Human capital and social capital: The rise of secondary schooling in America, 1910-1940. Journal of interdisciplinary history, 29(4), 683-723. https://doi.org/10.1162/002219599551868

Hashi, I., \& Krasniqi, B. (2011). Entrepreneurship and SME growth: evidence from advanced and laggard transition economies. International Journal of Entrepreneurial Behavior \& Research, 17(5), 456-487. https://doi.org/10.1108/13552551111158817

Havolli, Y., \& Ahmeti, S. (2013). Deindustrialization of Kosovo and establishment of the private sector in Kosovo-Obstacles. ILIRIA International Review, (1). https://doi.org/10.21113/iir.v3i1.95

Holden, L., \& Biddle, J. (2017). The introduction of human capital theory into education policy in the United States. History of Political Economy, 49(4), 537-574. https://doi.org/10.1215/00182702-4296305

Kosovo Agency of Statistics. (2019). Statistical Repertoire of Economic Enterprises in Kosovo.

Krasniqi, B. (2006). Size, age and firm growth: Econometric evidence from SME sector in Kosova. International Journal of management and Entrepreneurship, 2(1), 57-68.

Krasniqi, B., \& Lajqi, S. (2018). Gibrat's law and Jovanovic's learning theory: an empirical test for small firms in a postconflict economic setting. Ekonomski pregled, 69(3), 251-268. https://hrcak.srce.hr/202517

Havolli, Y. (2004) Human resource management, 2004, Riinvest.

Mamuneas, T. P., Savvides, A., \& Stengos, T. (2006). Economic development and the return to human capital: A smooth coefficient semiparametric approach. Journal of Applied Econometrics, 21(1), 111-132. https://doi.org/10.1002/jae.813

OECD (2004). $2^{\text {nd }}$ OECD Conference of Minister responsible for Small and Medium-Sized Enterprises (SMEs) Promoting Entrepreneurship and Innovative SMEs in global economy: Towards a more responsible and inclusive globalisation Istanbul, Turkey 3-5 June 2004, p. 5. Oxford English Dictionary.

Petty, W. (1690) Political Arithmetik, or a Discourse Conceirning the Extent and Value of Lands, People, Buildings. Reprinted in C.H. Hull (1899) The Economic Writings of Sir William Petty. Cambridge: Cambridge University Press.

Riinvest Institute. (2007). Business Climate in Kosovo from a Business Perspective, Prishtine: Riinvest Institute Schultz, T. W. (1960). Capital formation by education. Journal of Political Economy, 68(6), 571-583. https://doi.org/10.1086/258393

Voca, Z., \& Havolli, Y. (2019). The Impact of Human Resources Development on Small and Medium Enterprises (SMEs) Performance. Journal of Economics and Management Sciences, 2(2), p45-p45.

Williams, C. C., \& Krasniqi, B. (2018). Explaining informal sector entrepreneurship in Kosovo: An institutionalist perspective. Journal of Developmental Entrepreneurship, 23(02). https://doi.org/10.1142/S1084946718500115 
Williams, N., \& Krasniqi, B. A. (2018). Coming out of conflict: How migrant entrepreneurs utilise human and social capital. Journal of International Entrepreneurship, 16(2), 301-323. https://doi.org/10.1007/s10843-017-0221-4.

Woldie, A., Leighton, P., \& Adesua, A. (2008). Factors influencing small and medium enterprises (SMEs): An exploratory study of owner/manager and firm characteristics.

\section{Copyrights}

Copyright for this article is retained by the author(s), with first publication rights granted to the journal.

This is an open-access article distributed under the terms and conditions of the Creative Commons Attribution license (http://creativecommons.org/licenses/by/4.0/). 